\title{
The Influence of Neighborhood Types on Active Transport in China's Growing Cities
}

\section{Citation}

Guan, ChengHe, Sumeeta Srinivasan, Bo Zhang, Liangjun Da, Jialin Liu, \& Chris Nielsen. 2020. The Influence of Neighborhood Types on Active Transport in China's Growing Cities. Transportation Research Part D: Transport and Environment 80: 102273.

\section{Permanent link}

http://nrs.harvard.edu/urn-3:HUL.InstRepos:42643004

\section{Terms of Use}

This article was downloaded from Harvard University's DASH repository, and is made available under the terms and conditions applicable to Open Access Policy Articles, as set forth at http:// nrs.harvard.edu/urn-3:HUL.InstRepos:dash.current.terms-of-use\#OAP

\section{Share Your Story}

The Harvard community has made this article openly available.

Please share how this access benefits you. Submit a story.

Accessibility 


\title{
The influence of neighborhood types on active transport in China's growing cities
}

ChengHe Guan ${ }^{123^{*}}$, Sumeeta Srinivasan ${ }^{4}$, Bo Zhang ${ }^{5}$, Liangjun $\mathrm{Da}^{6}$, Jialin Liu ${ }^{12}$, Chris Nielsen ${ }^{2}$

${ }^{1}$ New York University Shanghai, China

${ }^{2}$ Harvard-China Project, John A. Paulson School of Engineering and Applied Sciences, Harvard University, USA

${ }^{3}$ PEAK Urban programme, Centre on Migration, Policy and Society, University of Oxford, UK

${ }^{4}$ Department of Urban and Environmental Policy and Planning, Tufts University, USA

${ }^{5}$ School of Management, China University of Mining \& Technology (Beijing), China

${ }^{6}$ The Shanghai Key Lab for Urban Ecological Processes and Eco-Restoration, East China Normal University,

China

*Corresponding author email: chenghe.guan@nyu.edu

\begin{abstract}
Rapid urban expansion in China has created both opportunities and challenges for promoting active transport in urban residential communities. Previous studies have shown that the urban form at the city scale has affected active transport in Chinese cities. However, there is less agreement about how the physical and social variations of neighborhood types should be addressed. This research investigates the four most representative neighborhood types found in Chinese cities: traditional mixed-use, slab block work-unit, gated community, and resettlement housing. Household travel diaries conducted in Chengdu in 2016 were analyzed using binary logistic regressions, supplemented by informal onsite interviews. The findings indicate significant variations in the use and accessibility of active transport in each neighborhood type for non-work trips. This suggests that each neighborhood type may need different strategies for promoting active transport: (1) the traditional mixed-use neighborhoods are in need of intensified urban retrofitting projects to reclaim public open space; (2) the work-unit could benefit from comprehensive plans rather than a patchwork of projects; (3) while opening up gated communities can improve porosity across neighborhoods and promote active transport, the more pressing issue may be their inability to keep up with the transportation needs of the residents; and (4) residents of resettlement housing should have better access to employment using transit and non-motorized modes.
\end{abstract}


Keywords: neighborhood type; accessibility; gated community; work-unit; resettlement housing

\section{Acknowledgement}

This paper is sponsored by the Shanghai Pujiang Program, Grant Ref: 2019PJC076; the National Science Foundation of China (71834005); completed with support from the PEAK Urban Programme funded by UKRI's Global Challenge Research Fund, Grant Ref: ES/P01105 5/1. The authors received supports from the Zaanheh Project, an interdisciplinary project led by a team at and funded by NYU Shanghai. The Chengdu surveys were conducted by the Harvard-China Project on Energy Economy and Environment of the Harvard John A. Paulson School for Engineering and Applied Sciences, Harvard University, and the Research Center for Contemporary China (RCCC) of Peking University. 


\section{Introduction}

Chinese cities are experiencing rapid growth and Chinese urban neighborhoods are undergoing rapid transformation (Gao et al, 2016; Feng et al, 2017). In this context, there is an urgent need to plan for a sustainable low-carbon city (Cervero, 2013, Day 2017, Wang and Zhou, 2017).

Therefore, this question is key: Does neighborhood form influence active transport and how best to promote it in various types of neighborhoods? Knowledge about the relationship between neighborhood typology and active transport can provide suitable transportation and planning strategies (Cao, 2015; Hu et al, 2018; Guan et al, 2019).

In North America, the influence of the built environment on active transport has been studied in detail (Crane, 2000; Giuliano and Narayan, 2003; Cao et al., 2009). While the empirical evidence is strong on how the overall spatial structure of a city has impacted active transport, less is known about how the design characteristics and social environment of smaller neighborhood areas stimulate active transport (Shen, 2000; Yang, 2005; Pan et al., 2009). In China, the importance of using neighborhood types to explain active transport has been recognized (Wang and Zhou, 2017). For example, the unique perspective of work-unit has led to debates over job-housing balances. However, few studies to measure active transport have incorporated cultural and social variables of neighborhood types (Wang and Zhou, 2017). Moreover, few studies have related the results of travel diary data analysis to the truth on the ground by neighborhood types. In addition, most existing studies focused on China's coastal cities (Wang and Zhou, 2017).

This study investigates an inland city of China - Chengdu. It uses a travel diary survey of 1,048 individuals conducted in 2016 in order to discover the connections between urban neighborhood typology and active transport. Onsite interviews were also conducted to gain further knowledge of active transport from the physical ground-truth and social conditions of neighborhoods that related to Chinese culture. The variables were categorized into access to fresh food, participation in recreational activities, and social connectivity to understand accessibility, as identified by Wang and Zhou (2017). The categorization of neighborhood types was based on time-periods developed (Pan et al., 2009), property management (Zhao and Chai, 2013), spatial configuration of design (planned or unplanned) (Gao et al., 2016), and socioeconomic characteristics (welfare or commodity). Our study is based on the evidence from 
these earlier studies and adopts multiple criteria from them to reflect the rapid process of change underway in urban neighborhood in inland China.

\section{Literature review}

\subsection{Neighborhood typology and urban housing transition in China}

The initiation of China's lifang system of urban residential neighborhoods can be traced back to the Tang Dynasty (600-900), during which enclosed neighborhoods served as "the foundation of the most enduring administrative apparatus," the baojia system (Rowe et al., 2016). These premodern urban neighborhood systems were then integrated with the concept of neighborhood unit that Clarence Perry proposed in the 1920s (Perry, 1929). The neighborhood unit design gained popularity among Chinese planners, who used it as a framework to design functional, selfcontained, desirable neighborhoods in industrializing cities (Kan et al., 2017). As China's economic reforms unfolded in the 1980s, urban communities in the form of enclosed residential neighborhoods prevailed both as governance structures and as physical boundaries (Kan et al., 2017). Most recently, the State Council issued guidelines calling for opening up enclosed residential neighborhoods (State Council, 2016), which will certainly have a prolonged impact on the formation of China's urban neighborhoods.

This paper identifies the four most representative neighborhood types in contemporary China. They are traditional mixed-use, slab block work-unit (danwei), gated community, and resettlement or affordable housing. Traditional neighborhoods in China, such as Shanghai's lane houses (Li-Long) and Beijing's courtyard houses (Hutong), are not unfamiliar to international readers. However, the traditional neighborhoods in China's inland cities are less discussed. Chengdu's Xiang-Zi, for example, inherited a traditional form that follows a north-south axis, which can be dated back to the Kaiming Kingdom (Qin, 2015). Designed as a human-scale neighborhood, Xiang-Zi was claimed to produce high social coherence. As a consequence of urban regeneration in the 1990s, many of the Xiang-Zi neighborhoods were renovated to become mixed-use communities with diverse commercial, office, and government functions, while preserving the traditional spatial forms.

The work-unit concept brought a welfare-oriented public rental housing system to China (Huang, 2004). Introduced in 1948 and formalized in 1951 with the passage of national labor insurance regulations, work-unit neighborhoods have since become the most prevalent type in 
China (Bray, 2005). A work-unit constructs its own housing for its workers, consistently as parallel slab block walk-up apartments (Bray, 2005; Rowe et al, 2016). By the end of the 1950s almost 90 percent of the urban workforce resided either in state-owned work-unit housing or in work-unit housing owned by a collective (Bray, 2005). The work-unit organization prevailed into the early 1990s and then was phased out (Kan et al., 2017). Today, a high percentage of renters in work-unit neighborhoods are transitory, which has substantially reduced community ties among residents (Rowe et al., 2016).

In the late 1980s, a national housing reform program was implemented to privatize the housing market (Zhao and Chai, 2013). This enabled urban residents to purchase their work-unitbuilt housing for a nominal price, or in some cases, to purchase units some distance from their employment location. They could also purchase commodity housing from the market, and through their work unit they could obtain a lump sum government subsidy for this purchase (Zhao and Chai, 2013). As a result, gated communities emerged that are largely populated by middle-income households ( $\mathrm{Li}$ et al., 2012), and which often assumed a super block configuration in China's context (Kan et al., 2017). Residents of these gated communities often extend their activity space beyond their neighborhood (Huang, 2003), unlike residents of stateowned compounds where people lived and worked in a self-contained community (Zhao and Chai, 2013).

As the commodity housing market sustained premium prices, the State Council announced in 1998 a policy promoting a special type of housing targeting the low-income group, so-called affordable housing (State Council, 1998). At first this policy was implemented only in municipalities or Zhixiashi in the east coast (Zhao and Chai, 2013), but it soon spread out to affect the housing landscape across China. In a related development, since the late 1990s, rapid expansion of cities led to many workers' relocation, and initially, local governments were responsible for providing resettlement housing. As private developers came on board in the 2000s, local governments limited their role to land development while providing guidelines for real estate development. They conceded both development rights and resettlement responsibility to private entities. Resettlement housing, often low cost and sometimes free to relocated families, resembles affordable housing both in terms of physical layout and remote location.

\subsection{Neighborhood typology and active transport}


Active transport refers to the usage of people's physical activity for means of travel, such as walking and bicycling (Forsyth and Krizek, 2010; Cao, 2015). The key factors affecting active transport include trip characteristics (purpose of travel and trip length), social economic conditions of residents (income and vehicle ownership), built environment (infrastructure and neighborhood types), and accessibility (to public amenities and city center) (Pan et al., 2009; Forsyth and Krizek, 2010; Cao, 2015; Day, 2017; Lin, 2018). The connection between the built environment and active transport is a central question in land use and transportation studies and policy making (Handy and Clifton, 2001; Handy, 2005; Cao et al., 2009; Forsyth and Krizek, 2010).

Scholars have started to incorporate housing types and neighborhood categories (Schwanen and Mokhtarian, 2005; Cao, 2010; Shen et al., 2015). In the United States, the categories include traditional (Handy and Clifton, 2001; Cao et al., 2009), new urbanist (Day, 2003; Rodriguez and Khattak, 2006), urban (Bhat and Eluru, 2009), transit-oriented (Cervero, 2007), and suburban (Bhat and Eluru, 2009; Forsyth and Crewe, 2009). These five types are defined according to urban intensity, land use diversity, and other attributes of urban form (Shen et al., 2015). Cervero and Kockelman (1997) devised three categories to describe elements of active transport design, which they called the "three Ds": "diversity," "design," and "density," which was then expanded to include access to "destination" and "distance" to public transportation (Ewing and Cervero, 2010). Later, the list of "Ds" was further expanded to include "demand management" such as parking supply and demographics. More recent studies relate the physical dimensions of neighborhood type to pedestrian-friendly design by controlling for self-selection using perceived neighborhood characteristics (Cao, 2015).

While the relationship between neighborhood form and active transport remains inconclusive in the United States (Pan et al., 2009), studies in China have agreed on the uniqueness of certain neighborhood types (Wang and Zhou, 2017). For example, residents of work-unit compounds have been reported to travel shorter distances and times and have a lower percentage of automobile dependency, compared with residents of commodity housing communities (Zhao and Chai, 2013; Wang and Zhou, 2017). Pan et al. (2009) recognized the importance of neighborhood type on active transport in China, surveyed over 1,700 residents in selected neighborhoods of Shanghai. The study compared traditional neighborhood with two planned communities and one commodity housing. The results showed that people who live in 
neighborhoods better equipped with pedestrian walkways do walk more and make active transport modes feasible options. The variables selected focused on the physical characteristics of neighborhood forms and their locations relative to the city center. The regression models controlled for income and household features. Zhao and Chai (2013) compared affordable housing with commodity housing and danwei communities in Beijing. They used a two-day travel diary collected in 2007. The sample comprised 652 residents. The results show that workunit residents travel less than people from other neighborhood types and hence can contribute positively to the sustainability of transportation. Shen et al. (2015) further distinguished relocation housing from affordable housing. Using GPS-enabled tracking devices and activity diaries in Beijing, four types of neighborhoods were under investigation: work-unit danwei, relocated community, low-cost neighborhood, and market housing. They found the spatial temporal stability varied for the 709 residents in relocated housing but not in work-unit neighborhoods.

Most of the previous studies, conducted in large coastal areas in China, claimed that residents of work-unit are more likely to choose active transport than other neighborhood types (Zhao and Chai, 2013). In recent year, inland cities were also starting to experience higher car ownership, rapid urban sprawl, and neighborhood transformation (Pan et al., 2009; Wang and Zhou, 2017). Gao et al. (2016) studied Xi'an, a major city in inland China, using cross-sectional survey data collected for adults (18 years old and above) in July and August of 2013. The researchers categorized neighborhood types by time-periods in additional to density. The four neighborhood types were traditional and unplanned, traditional and planned (work-unit), contemporary and high density, and contemporary and low density. Gao et al. (2016) found evidence to support the influence of physical activity over leisure or non-work trips in traditional and unplanned and contemporary and high density.

In summary, studies suggested the importance of literature contribution on the impact of neighborhood types on active transport (Day, 2017). The transferability of conclusions between China and western countries is low because of the uniqueness of China's housing resource (Feng et al., 2014 and 2017) and neighborhood transformation (Wang and Zhou, 2017). The coastal Chinese cities have been studied more than the rapidly urbanizing inland cities. Also, few empirical studies have combined travel diary analysis with ground-truthing of neighborhoods related to Chinese cultural and social conditions. 


\section{Methodology}

\subsection{Study area}

Chengdu, located in the inland area of China, is a pioneer city of coordinated urban-rural development since 2003 (Qin, 2015). The built-up area of the central city increased almost 20fold between 1949 (18 km2) and 2011 (355 km2) (Qin, 2015; CSB, 2017). Despite the impact of urban sprawl, Chengdu ranked high among Chinese cities for livability and percentage of active transport (National Resources Defense Council, 2017). This study covers most of Chengdu's urban area (except for the Tianfu New District) within the fourth ring road and selects 40 neighborhoods in various locations. To further examine people's choices of active transport among various neighborhood types, one from each of the four neighborhood types (traditional mixed-use, neighborhood, a slab block work-unit, gated community, and resettlement housing) were selected. We consulted local experts for the selection of neighborhoods that can be representative of its type. We then examined the locations of the neighborhoods against Baidu and Google Earth Maps to make sure they are located in areas with other neighborhoods of similar types. For example, we choose traditional mixed-use neighborhood PSU 132, which is located in the historical area of inner city of Chengdu along the Jinjiang River, see Figure 1. 


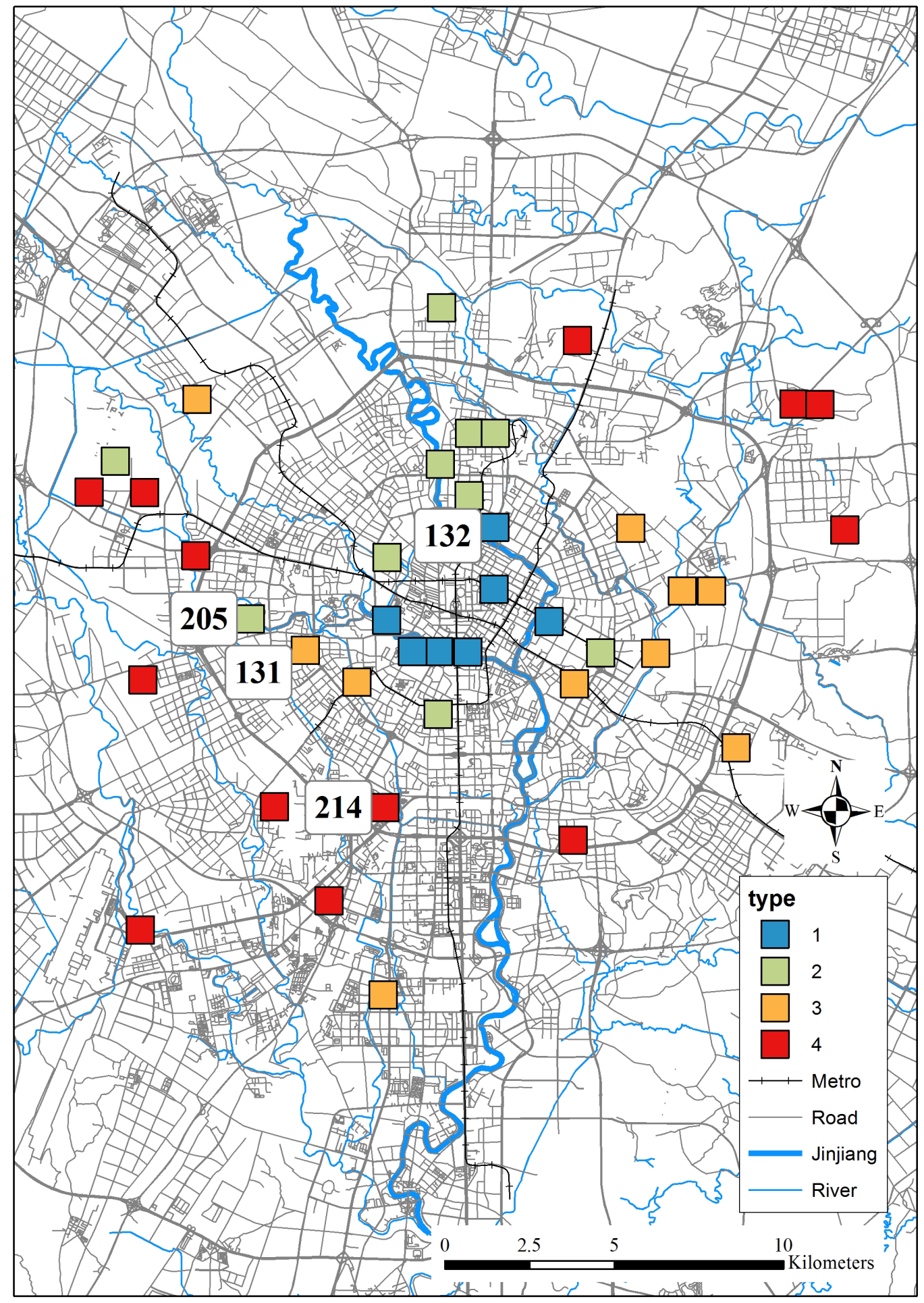

Figure 1. Geographical location of the 40 sampling neighborhoods and the four selected neighborhoods for accessibility interview (PSU 132, 205, 131, 214). Type 1: traditional mixeduse; Type 2: slab block work-unit; Type 3: gated community; type 4: resettlement housing. 


\subsection{Data collection, field survey, and onsite interview on accessibility}

A research team of Peking University conducted the fieldwork during June and July 2016. 1,048 valid individual interviews were completed. The survey questionnaire included vehicle ownership, spending on transportation, socioeconomic condition, accessibility to amenities, attitudes toward environment and transportation issues, and travel diaries, see Appendix 1 for the sample questions. The sampling frame for the survey is population density in half-square minutes (HSMs), taking population statistics from the 2015 Chengdu Statistical Yearbook. The first field survey on accessibility was conducted in June 2017, two groups of researchers guided by locals visited the four selected neighborhoods. The purpose of this survey was to confirm the accuracy of spatial data collected online. The second field survey (onsite interviews) was conducted in November 2017 by a research team following a standard protocol of interview location selections: public plazas, pedestrian sidewalks, community entrances, and transit stops. In cases in which interviews with residents were interrupted, additional interviews were conducted at alternative locations. In total, 140 interviews were conducted (35 per neighborhood). After filtering for missing information, there were 112 valid respondents to the survey. In addition, personal interviews were conducted with five groups of local developers and two groups of community organization members. Table 1 shows the statistical summary of trips by neighborhood types. Table 2 provides explanation of variables in the context of Chengdu.

Table 1. Statistical summary of trips by neighborhood types (40 neighborhoods).

\begin{tabular}{lrrrrr}
\hline $\begin{array}{l}\text { Neighborhood Type } \\
\text { Travel mode }\end{array}$ & $\begin{array}{c}\text { Mixed-use } \\
\text { Trip No. }\end{array}$ & $\begin{array}{c}\text { Work-unit } \\
\text { Trip No. }\end{array}$ & $\begin{array}{c}\text { Gated } \\
\text { Trip No. }\end{array}$ & $\begin{array}{c}\text { Resettlement } \\
\text { Trip No. }\end{array}$ & Total \\
\hline Work trip & & & & & \\
Active & 25 & 44 & 14 & 51 & 134 \\
E-bike & 32 & 38 & 50 & 81 & 201 \\
Motorcycle & 3 & 13 & 10 & 13 & 39 \\
Car & 26 & 22 & 56 & 39 & 143 \\
Transit & 12 & 28 & 46 & 24 & 110 \\
Other & 3 & 8 & 5 & 18 & 34 \\
Sub total & 101 & 153 & 181 & 226 & 661 \\
Non-work trip & & & & & \\
Active & 135 & 243 & 209 & 289 & 876 \\
E-bike & 57 & 55 & 80 & 120 & 312 \\
Motorcycle & 3 & 25 & 12 & 14 & 54 \\
Car & 56 & 45 & 72 & 48 & 221 \\
Transit & 23 & 45 & 91 & 30 & 189
\end{tabular}




\begin{tabular}{lrrrrr}
\hline $\begin{array}{l}\text { Neighborhood Type } \\
\text { Travel mode }\end{array}$ & $\begin{array}{c}\text { Mixed-use } \\
\text { Trip No. }\end{array}$ & \multicolumn{1}{c}{$\begin{array}{c}\text { Work-unit } \\
\text { Trip No. }\end{array}$} & $\begin{array}{c}\text { Gated } \\
\text { Trip No. }\end{array}$ & $\begin{array}{c}\text { Resettlement } \\
\text { Trip No. }\end{array}$ & Total \\
\hline Other & 2 & 3 & 0 & 5 & 10 \\
Sub total & 276 & 416 & 464 & 506 & 1662 \\
Total trip & & & & & \\
Active & 160 & 287 & 223 & 340 & 1010 \\
E-bike & 89 & 93 & 130 & 201 & 513 \\
Motorcycle & 6 & 38 & 22 & 27 & 93 \\
Car & 82 & 67 & 128 & 87 & 364 \\
Transit & 35 & 73 & 137 & 54 & 299 \\
Other & 5 & 11 & 5 & 23 & 44 \\
Total & 377 & 569 & 645 & 732 & 2323 \\
No of Neighborhood & 7 & 10 & 10 & 13 & 40 \\
\hline
\end{tabular}

Note: Active trips include walking and bicycling and non-active trips include all other modes.

Primary Sampling Unit (PSU) was used in the neighborhood sampling process.

Table 2. Explanation of variable selections in the context of Chengdu.

\begin{tabular}{|c|c|c|c|}
\hline Variable & Definition & Category & Context \\
\hline Work trip & $\begin{array}{l}\text { Regular commuting between one's } \\
\text { home and workplace/school }\end{array}$ & Mode & Work trip and study trip \\
\hline Non-work trip & $\begin{array}{l}\text { Leisure purposes and other non-work } \\
\text { non-study trips }\end{array}$ & Mode & Other trips \\
\hline Income & Percentage of low income household & $\begin{array}{l}\text { Socio- } \\
\text { economic }\end{array}$ & $\begin{array}{l}\text { Categorized into low, } \\
\text { middle, and high }\end{array}$ \\
\hline Gender & Male or Female & $\begin{array}{l}\text { Socio- } \\
\text { economic }\end{array}$ & Male is 0 , female is 1 \\
\hline Age & Age of respondents & $\begin{array}{l}\text { Socio- } \\
\text { economic }\end{array}$ & $\begin{array}{l}\text { The average age is } 41.8 \text {, } \\
\text { ranging from } 18-70\end{array}$ \\
\hline Education & Years of education received & $\begin{array}{l}\text { Socio- } \\
\text { economic }\end{array}$ & Ranging from 0 to 20 \\
\hline $\begin{array}{l}\text { Total travel } \\
\text { time }\end{array}$ & Door to door travel time & Trip & - \\
\hline Wait time & Waiting for bus, subway, or taxi & Trip & $\begin{array}{l}\text { Not applicable for active } \\
\text { travel }\end{array}$ \\
\hline Travel time & Travel time exclude waiting time & Trip & - \\
\hline $\begin{array}{l}\text { Percentage } \\
\text { built }\end{array}$ & $\begin{array}{l}\text { Only one variable in this category } \\
\text { included. Other built form conditions } \\
\text { are systematically imbedded in } \\
\text { neighborhood types }\end{array}$ & $\begin{array}{l}\text { Built } \\
\text { environment }\end{array}$ & $\begin{array}{l}\text { In } 2016 \text {, the city was } \\
\text { developing rapidly, many } \\
\text { construction sites for real } \\
\text { estate development and } \\
\text { metro lines }\end{array}$ \\
\hline Alternative & $\begin{array}{l}\text { Number of available travel mode } \\
\text { options }\end{array}$ & Option & Ranging from 0 to 5 \\
\hline Car & Number of privately owned vehicle & Ownership & Ranging from 0 to 4 \\
\hline Motorcycle & $\begin{array}{l}\text { Number of privately owned } \\
\text { motorcycle }\end{array}$ & Ownership & Ranging from 0 to 4 \\
\hline
\end{tabular}




\begin{tabular}{|c|c|c|c|}
\hline Variable & Definition & Category & Context \\
\hline E-bike & Number of privately owned E-bike & Ownership & Ranging from 0 to 4 \\
\hline Type & Typology of neighborhood & Neighborhood & $\begin{array}{l}\text { Neighborhood categorized } \\
\text { based on spatial formation }\end{array}$ \\
\hline $\begin{array}{l}\text { Historical } \\
\text { mixed-use }\end{array}$ & $\begin{array}{l}\text { Indigenous Xiangzi type of } \\
\text { neighborhoods mixed with } \\
\text { contemporary development }\end{array}$ & Neighborhood & $\begin{array}{l}\text { Mainly in the historical } \\
\text { district }\end{array}$ \\
\hline $\begin{array}{l}\text { Slab block } \\
\text { work-unit }\end{array}$ & $\begin{array}{l}\text { Work-unit, or Danwei, constitutes a } \\
\text { form of social organization } \\
\text { following the principle of organizing } \\
\text { workplace and housing as a spatial } \\
\text { unit }\end{array}$ & Neighborhood & $\begin{array}{l}\text { Located in the inner city, } \\
\text { north and northeast of the } \\
\text { city center }\end{array}$ \\
\hline $\begin{array}{l}\text { Gated } \\
\text { community }\end{array}$ & $\begin{array}{l}\text { Residential community containing } \\
\text { controlled entrances characterized by } \\
\text { perimeter walls }\end{array}$ & Neighborhood & $\begin{array}{l}\text { Location varies, concentrated } \\
\text { between } 2 \text { nd and 3rd ring } \\
\text { roads }\end{array}$ \\
\hline $\begin{array}{l}\text { Resettlement } \\
\text { housing }\end{array}$ & $\begin{array}{l}\text { Rural or urban dwellers resettled to } \\
\text { high-density housing real state }\end{array}$ & Neighborhood & $\begin{array}{l}\text { Consequence of urban } \\
\text { sprawl in Chengdu }\end{array}$ \\
\hline
\end{tabular}

The investigation on accessibility measures is based both on existing literatures and local knowledge. We followed the arguably general agreement that accessibility should measure (1) potential to interact; (2) attractiveness of non-work opportunities; (3) travel impedance; and (4) prospective of integration (to a larger urban area via transport system or economic activities) (Alonso, 1964, Ben-Akiwa and Leman, 1985; Kwan, 1998; Miller, 2018). In addition, these measures should be addressed in the context of specific neighborhood types. We asked each respondents the most important issues affecting his/her decision on choosing active transport. We summarized the following four categories to be the most influential factors in the context of urban neighborhoods in Chengdu: (1) availability of public space and recreational sites; (2) access to fresh food market and public amenities; (3) quality of pedestrian road network; and (4) connectivity to outside the neighborhood, see Table 3.

Table 3. Summary of accessibility variables in the four selected neighborhoods.

\begin{tabular}{ll}
\hline Variables & Explanation \\
\hline Public \& recreational space & Availability of public space for recreational purposes \\
Urban block level & Number of public space at the urban block level \\
Type (Urban block level) & Type of public space at the urban block level \\
Size (Urban block level) & Area of the public space in hectare \\
Neighborhood level & Number of public space at the neighborhood level \\
Type (Neighborhood level) & Type of public space at the neighborhood level
\end{tabular}




\begin{tabular}{ll}
\hline Variables & Explanation \\
\hline Size (neighborhood level) & Area of the public space in hectare \\
City level (adjacent) & Accessible city level public space \\
\hline Fresh food market & Availability of fresh food market \\
Number & Number of fresh food market in the neighborhood \\
Size & Size of fresh food market in the neighborhood \\
Type & Type of fresh food market in the neighborhood \\
Other & Other available amenity \\
\hline Pedestrian-friendly street & Availability of pedestrain-friendly facilities \\
Pedestrian sidewalk & Availability of pedestrian sidewalk \\
Cycling & Availability of cycling lane \\
\hline Connectivity & Connection to other parts of Chengdu \\
Bus stops & Number of bus stops \\
Metro lines & Number of metro lines \\
Employment opportunity & Employment subcenters located within $2.0 \mathrm{~km}$ \\
CBD & Distance to CBD (km) \\
Job-housing balance & Collocation of employment opportunity and housing \\
\hline
\end{tabular}

\subsection{Research design}

The purpose of data analysis was to identify significant independent variables that influenced choices of active transport modes, and to test the likelihood that residents of each neighborhood type would choose active transport over other modes. The travel diary data were analyzed in STATA, a statistical software. To reflect high diversity of residents' economic class in Chengdu's urban neighborhoods, household income was controlled for the analysis of vehicle ownership. The discrete or qualitative choice model was adopted from Ben-Akiva and Lerman (1985), which can be expressed as follows:

$P_{n}\left(i \mid C_{n}\right)=\frac{e^{V_{\text {in }}}}{e^{V_{\text {in }}+e^{V_{j n}}}}$

$V_{\text {in }}=\beta_{1} X_{\text {in } 1}+\beta_{2} X_{\text {in } 2}+\cdots+\beta_{k} X_{\text {ink }}$

$V_{j n}=\beta_{1} X_{j n 1}+\beta_{2} X_{j n 2}+\cdots+\beta_{k} X_{j n k}$

where $P_{n}\left(i \mid C_{n}\right)$ is the likelihood of a resident selecting mode $i$ from option C; $X_{i n}$ and $X_{j n}$ are independent variables including attributes of trip cost and time, characteristics of decision 
maker's age, gender, and income; and $\beta_{k}$ is a vector parameter of $X_{i n}$ and $X_{j n}$ that influences mode choices. Binary logistic regression technique was adopted to derive the odds of choosing active transport and to overcome the lack of travel route information, represented as follows:

$\frac{P_{\text {non }}}{P_{\text {active }}}=e^{\left(V_{\text {in }}-V_{j n}\right) X}$

$L_{n}\left(\frac{P_{\text {non }}}{P_{\text {active }}}\right)=\left(\beta_{\text {non }}-\beta_{\text {active }}\right) X$

where $P_{\text {non }}$ is the probability of a resident choosing non-active transport mode, and $P_{\text {active }}$ is the probability of active transport mode. The formula is derived following the framework of Pindyck and Rubinfeld (1998) and Pan et al. (2009).

\section{Results}

\subsection{Vehicle ownership, household income, and neighborhood typology}

Table 4 tabulates vehicle ownership by low-, middle-, and high-income categories. Income stratification was based on household income. The low income cut-off was below 15,000 RMB and the high-income cut-off was 75,000RMB. We did not classify neighborhoods as low- or high-income, as the diversity of income was high in some neighborhoods. High-income households in all neighborhood types had higher rates of car ownership than the middle- and low-income households. In the mixed-use neighborhoods, the high-income households had the lowest rate of car ownership of $25.7 \%$ while in the work-unit neighborhoods, the high-income households had the highest rate of car ownership of $71.4 \%$. The results show that the advantage of high job-housing balance in the work-unit neighborhoods had become insignificant in terms of car ownership. The gated community had the smallest gap of car ownership percentage by income groups. In the resettlement housing, high percentages of both high- and low-income groups owned cars and bicycles. In addition, the population in the mixed-use neighborhood had significantly more high income households than other neighborhoods, because of the cluster of high-income jobs around the Central Business District (CBD) and the attractiveness of a central city location.

Table 4. Vehicle ownership by neighborhood typology and income at the household level. 


\begin{tabular}{lllllll}
\hline & \multicolumn{6}{l}{ Neighborhood Type } \\
Household Income & Mixed-use & Work-unit & Gated & Resettlement & Total \\
\hline Low income & No. of household & 0 & 22 & 32 & 33 & 87 \\
Bicycle & \% own & - & $13.6 \%$ & $34.4 \%$ & $60.6 \%$ & $47.1 \%$ \\
& No. owned & 0 & 3 & 15 & 23 & 41 \\
Car & \% own & $0.0 \%$ & $4.5 \%$ & $12.5 \%$ & $12.1 \%$ & $10.3 \%$ \\
& No. owned & 0 & 1 & 4 & 4 & 9 \\
\hline Middle income & No. of household & 12 & 146 & 158 & 240 & 556 \\
Bicycle & \% own & $50.0 \%$ & $45.2 \%$ & $53.8 \%$ & $44.6 \%$ & $57.9 \%$ \\
& No. owned & 8 & 71 & 110 & 133 & 322 \\
Car & \% own & $0.0 \%$ & $19.9 \%$ & $20.3 \%$ & $17.9 \%$ & $19.2 \%$ \\
& No. owned & 0 & 29 & 34 & 44 & 107 \\
\hline High income & No. of household & 183 & 60 & 71 & 82 & 396 \\
Bicycle & \% own & $40.4 \%$ & $31.7 \%$ & $47.9 \%$ & $53.7 \%$ & $52.3 \%$ \\
& No. owned & 92 & 20 & 40 & 55 & 207 \\
Car & \% own & $25.7 \%$ & $71.4 \%$ & $54.9 \%$ & $68.3 \%$ & $49.2 \%$ \\
& No. owned & 51 & 42 & 44 & 58 & 195 \\
\hline Note: Total
\end{tabular}

Note: Total number of households is 1,048 with 9 no answers.

\subsection{Logistic regression}

Binary logistic regressions were estimated for whether a trip used active transport or not for work trips and for leisure or other types of non-work trips. It was necessary to separate the two types because mode choice options in Chengdu tended to diverged by purpose. The neighborhood type was treated as a dummy factor variable. Both models were fitted with the robust estimate of variance, which included an estimator of errors that is robust to the deviation from the standard case. As shown in Table 5, both models yielded statistically significant results for income and trip time. Age, education, total travel time, and percentage built were all statistically significant for non-work trips. For example, the odd ratio for income was 1.027 for work trips and 1.037 for non-work trips, which means the probability of choosing active transport over motorized mode was higher for low income households. In conclusion, the results show that across the board, choice of active transport for non-work trips was more affected by social economic factors, while neighborhood type had influence on all trips.

To elaborate on whether neighborhood type had significant association with active transport, the regression model used the traditional mixed-use neighborhood as the baseline. For work trips, gated community was statistically significant ( 5 percent level), indicating neighborhood types had a strong impact on active transport. This finding reconfirmed the conclusion made 
earlier. For non-work trips, none of the variables were significant when car ownership variable included, which indicates that neighborhood types had weaker impact on active transport. The negative sign of coefficients for gated community suggests that motorized travel was preferred over active transport. The gated community had the smallest magnitude of the odds ratio for work trips (0.382) and the mixed-use neighborhood had the smallest magnitude of odds ratio for non-work trips, also suggesting active transport is the least preferred in this type of neighborhood.

Table 5. Binary logistic regression on active transport and neighborhood typology

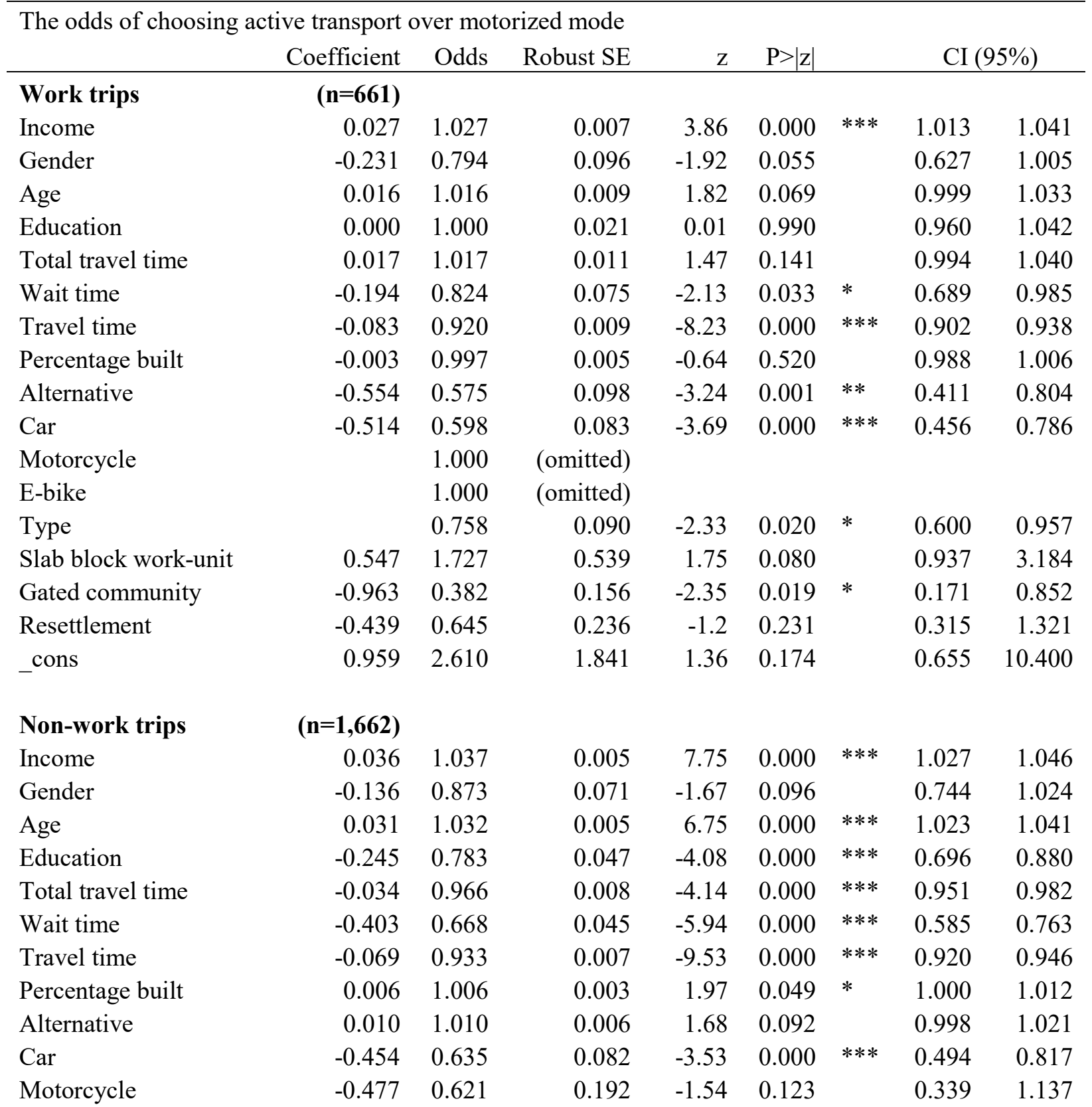




\begin{tabular}{|c|c|c|c|c|c|c|c|c|}
\hline \multicolumn{9}{|c|}{ The odds of choosing active transport over motorized mode } \\
\hline & Coefficient & Odds & Robust SE & $\mathrm{z}$ & $\mathrm{P}>|\mathrm{z}|$ & & \multicolumn{2}{|c|}{$\mathrm{CI}(95 \%)$} \\
\hline E-bike & -1.254 & 0.285 & 0.032 & -11.06 & 0.000 & $* * *$ & 0.229 & 0.356 \\
\hline Type & - & 1.242 & 0.086 & 3.12 & 0.002 & $* * *$ & 1.084 & 1.423 \\
\hline Slab block work-unit & 0.011 & 1.012 & 0.226 & 0.05 & 0.959 & & 0.653 & 1.567 \\
\hline Gated community & 0.216 & 1.241 & 0.285 & 0.94 & 0.348 & & 0.791 & 1.947 \\
\hline Resettlement & 0.258 & 1.294 & 0.316 & 1.06 & 0.291 & & 0.802 & 2.087 \\
\hline cons & 1.093 & 2.985 & 1.531 & 2.13 & 0.033 & & 1.092 & 8.159 \\
\hline
\end{tabular}

Note: For work trips, Wald chi $2=162.91$; Prob $>$ chi $2=0.000$. For non-work trips, Wald chi2 $=$ 447.73; Prob $>\operatorname{chi} 2=0.000$.

\section{Accessibility and active transport in the four selected neighborhoods}

The significant variation of people's choices of active transport among different neighborhood types made it necessary to further investigate the spatial form of the four neighborhood typologies. One of each type were selected: a traditional mixed-use neighborhood in Renmin Beilu (PSU 132), a slab block work-unit neighborhood in Sunjia Wan (PSU 205), a gated community in Wai Shuangnan (PSU 131), and a resettlement housing in Xiaojia He (PSU 214). The transformations of the four selected neighborhoods were traced back to 2005 using satellite images acquired from Google Earth Pro, as illustrated in Figures 2 to 5. During the field survey in November 2017, the questions focused on cultural traditions and social conditions that were most related to active transport. Based on the responses from the onsite interviews, the most pressing issues on active transport and neighborhood forms were summarized as follows: Availability of public space and recreational sites, access to fresh food market and public amenities, quality of pedestrian road network, and connectivity to outside the neighborhood. Table 6 summarizes the spatial characteristics of the four neighborhoods. Table 7 shows the accessibility measures of the four neighborhoods.

Table 6. Characteristics of the four selected neighborhoods.

\begin{tabular}{lrrrr}
\hline Variables & Mixed-use & Slab Block & $\begin{array}{c}\text { Gated } \\
\text { Community }\end{array}$ & $\begin{array}{c}\text { Resettlement } \\
\text { Housing }\end{array}$ \\
\hline Neighborhood & PSU 132 & $\begin{array}{r}\text { PSU 205 } \\
\text { Sunjia Wan }\end{array}$ & PSU 131 & PSU 214 \\
Jiedao (subdistrict) & Renmin Beilu & Xiaojia He \\
Year built & 1985 & 1996 & 1992 & 2001
\end{tabular}




\begin{tabular}{lrrrr}
\hline Variables & Mixed-use & Slab Block & $\begin{array}{c}\text { Gated } \\
\text { Community }\end{array}$ & $\begin{array}{c}\text { Resettlement } \\
\text { Housing }\end{array}$ \\
\hline Year complete & 2016 & 2017 & 2002 & 2008 \\
Population & & & & \\
$\quad$ Number of housing estate & 9 & 18 & 15 & 6 \\
$\quad$ Number of households & 8,096 & 6,384 & 8,280 & 4,896 \\
Population density (p/km2) & 52,606 & 32,840 & 52,874 & 58,495 \\
Land use (hectares) & & & & \\
Residential site area & 4,617 & 5,832 & 4,698 & 2,511 \\
$\quad$ Other type of land use & 1,863 & 648 & 1,782 & 3,969 \\
Number of respondents & 27 & 30 & 25 & 30 \\
\hline
\end{tabular}

Note: Total number of respondents is 112 . This number only include final valid samples.

Table 7. Accessibility of the four selected neighborhoods

\begin{tabular}{|c|c|c|c|c|c|}
\hline & Neighborhood/ Jiedao & $\begin{array}{l}\text { Mixed-use/ } \\
\text { Remin Beilu }\end{array}$ & $\begin{array}{l}\text { Slab Block/ } \\
\text { Sunjia Wan }\end{array}$ & $\begin{array}{l}\text { Gated/ Wai } \\
\text { Shuangnan }\end{array}$ & $\begin{array}{c}\text { Resettlement/ } \\
\text { Xiaojia } \mathrm{He}\end{array}$ \\
\hline \multirow[t]{8}{*}{1} & Public \& recreational space & & & & \\
\hline & Urban block level & 0 & 0 & 12 & 5 \\
\hline & Type (Urban block level) & - & - & Playground & Playground \\
\hline & Size (Urban block level) & - & - & 2.1 & 1.1 \\
\hline & Neighborhood level & 1 & 1 & 0 & 2 \\
\hline & Type (Neighborhood level) & River bank & River bank & - & Plaza \\
\hline & Size (neighborhood level) & 1.5 & 0.8 & - & 3.5 \\
\hline & City level (adjacent) & Tianfu Plaza & Dongpo Park & None & None \\
\hline \multirow[t]{5}{*}{2} & Fresh food market & & & & \\
\hline & Number & 5 & 3 & 0 & 1 \\
\hline & Size & small & small & - & medium \\
\hline & Type & Free market & Street vendors & - & Free market \\
\hline & Other & - & - & $\begin{array}{l}\text { Shopping } \\
\text { Center }\end{array}$ & - \\
\hline \multirow[t]{3}{*}{3} & Pedestrian-friendly street & & & & \\
\hline & Pedestrian sidewalk & Primary street & No & All streets & All streets \\
\hline & Cycling & Primary street & No & Primary street & Primary street \\
\hline \multirow[t]{6}{*}{4} & Connectivity & & & & \\
\hline & Bus stops & 15 & 9 & 7 & 4 \\
\hline & Metro lines & 3 & 1 & 0 & 1 \\
\hline & Employment opportunity & 3 & 1 & 2 & 0 \\
\hline & $\mathrm{CBD}(\mathrm{km})$ & 1.5 & 6.1 & 5.2 & 7.4 \\
\hline & Job-housing balance & Medium & Low & Low & High \\
\hline
\end{tabular}


Note: The source of the data includes pre-interview mapping analysis using ArcGIS and open source data (Open Street Map, Baidu Point of Interests, Google Earth) and summary of onsite interview results.

\subsection{Traditional mixed-use neighborhood}

Renmin Beilu, a mixed-use neighborhood, is situated inside the first ring road on the north bank of the Fu River, conveniently connected to the historical district by three bridges: the Wanfu, Xinghui, and Beimen. At the time of this study a majority of the traditional Xiang-Zi areas had been converted to higher density developments; however, some narrow alleys remained intact. The neighborhood had one middle school, a few work-units, and two highly reputable hospitals. The neighborhood was centered around the Chengdu Badminton Stadium, which had been converted to an indoor retail center. A few high-rise buildings had been built along the Jiefang Road.

As shown in Table 7, the neighborhood is very centrally located, less than a mile from Tianfu Square, a large city-managed public space in the CBD. However, at the urban block (housing estate) level, there was no public space available. The only space for public recreational activities in the vicinity of the neighborhood was a park along the Fu River. A lack of public space in housing estates was one of the major factors that discouraged active transport for recreational purposes, as reported in the field survey. Additional motorized trips were generated by residents for exercise or physical activities. However, travel to fresh food markets and other retail businesses was very convenient for residents. Shops were well distributed across the neighborhood. Access to a pedestrian-friendly street network was good for those living on primary streets which had wide pedestrian walks and cycling paths. On the other hand, the smaller streets either had no sidewalks or had sidewalks which were blocked by street vendors and other street activities. As for connectivity measures, Renmin Beilu was well-serviced by both metro and bus. As mentioned earlier, it is conveniently located within the first ring road, and there are multiple metro stations within walking distance. "We don't drive during the weekend," said one of the interviewees, a young couple who had lived in the neighborhood for five years. "The traffic is really bad especially for holidays. The metro system is very convenient to get us where we want to go." See Figure 2. 


\subsection{Slab block work-unit neighborhood}

In terms of access to public space, Sunjia Wan closely resembled the mixed-use neighborhood in Renmin Beilu in that at the time of this study there was no public space inside the housing estates, and the only neighborhood-level public space available was the Dongpo Park along the riverbank. Due to a lack of public space, residents' daily exercise, plaza dance, and other social activities are pushed to the sidewalks, making active transport less attractive for residents. Fresh food markets and small retailers are distributed on the perimeter blocks at the street level. Daily consumption of basic necessities such as bread and butter is relatively convenient but with limited variety. In addition, incompatible land use issues are evident; for example, the customers in a hair salon had to deal with the smell from a butcher shop next door. "It is not safe to walk on the streets" was a common complaint amongst the interviewees in this neighborhood. The main roads were difficult to walk along; they either had no elevated walkway, or sidewalks were blocked by ongoing construction, street vendors, or ground floor commercial establishments, as shown in Figure 3. There were no designated bike lanes, and street signs and lane markings had deteriorated to the extent that they were not legible. It was also hard to cross the river as there were only two bridges on the Qingshui River and one of them was designated for private use only.

\subsection{Gated commodity housing neighborhood}

The Wai Shuangnan neighborhood is part of a larger gated community development. This planned community was developed in the late 1990s and most of the residential buildings were completed by 2005 . Situated outside the second ring road, the neighborhood is a product of China's super block developments.

The gated community provided a safe and comfortable environment for social and physical activities within each housing estate. Because the field survey was conducted during the daytime, when most adults were at work or school, we encountered a disproportionally high percentage of children accompanied by their grandparents. "We are reluctant to have kids play outside of the estates on the public streets," said one grandfather. Confining the children's activities within the fences gave them peace of mind. The elderly also enjoyed their time within the housing estates, as there was no open space to hang out outside of the gates. The neighborhood lacked social activities, organized events, or inter-community interaction. Many perimeter-block buildings had 
street-level retail and restaurants, which is not so different from Sunjia Wan, the work-unit neighborhood. However, more shopping activities were concentrated around the large shopping mall Ito Yokado. Plenty of parking space was provided. The pedestrian street networks were planned and well-maintained. On the arterial road, roads were in general too wide to cross. In addition, illegal occupation of public streets for private use was widely prevalent and zoning regulations were not stringently enforced. Wai Shuangnan also has easy accessibility to other parts of the city. In fact, at the time of the study the conurbation of similar super block developments had been extended to the fourth ring road, between two radiant arterials Longteng and Wuhou Roads. See Figure 4.

\subsection{Resettlement housing}

The resettlement housing neighborhood under investigation is in Xiaojia He, under the administration of the Xinbei Shequ/community. The neighborhood was primarily built on three villages and their farmlands. In 2001, approximately 8.95 hectares of land were prepared with a clear title for Xinbei resettlement housing. Construction started at the beginning of the following year and by 2005, three out of the sixteen planned housing estates were completed (see Figure 4.) Phase one included three blocks each for one of the original villages but all clustered together. The development, design, and construction were all administered by designated Stateowned Enterprises (SOE). From 2005 to 2010, the rate of construction accelerated, and private developers were involved through land tender, auction, and listing processes.

In this resettlement housing neighborhood, public spaces of different sizes were distributed throughout the neighborhood, ranging from small plots of green space to a central community plaza. "It is a successful resettlement example that many neighborhoods in Chengdu are modeled after," said one of the members of the Resident Committee who had lived in the neighborhood for more than fifteen years, "Our situations are better than those from other places with similar kinds of neighborhood." A local planner and other residents later confirmed his statement. A centrally located fresh food market was managed by the Jiedao Management Committee, whose responsibilities were to ensure food safety, virtuous competition, and selection of a balanced tenant composition. The facility was well-maintained. Accessibility to other public amenities was also high. The Xinbei community service clinic station, the community kindergarten, the high-tech district nursing home, and the high-tech district library were all clustered on a retail 
street next to the fresh food market. "The community-run shuttle bus is so convenient. It comes every 30 minutes or so circulating around the neighborhood," said one of the elderly residents who took the shuttle bus every day. Pedestrian sidewalks were sufficiently provided. Landscape features, road trees, and shrubs had matured to provide shade and block noise. In Figure 5, the middle right image illustrates a sidewalk that was typical of each sub-neighborhood development. The sidewalk was elevated, colored brick red, and well-shaded by road trees. Signs for the visually impaired were provided but not audio equipped. The scale was appropriate for both pedestrians and bikers, although most of the bikes ran on the asphalt roads. The two-lane streets were of the right scale that did not intimidate slow walkers crossing intersections. Connectivity to the outside was very low, both in terms of physical accessibility and social integration. The neighborhood is located between the historical city and the High-tech District. However, the so-called " 2.5 ring road" to the north, the third ring road to the south, the airport expressway to the east, and the Chengdu-Ya'an expressway to the west encapsulated the neighborhood. "It is hard to walk or bike to the adjacent neighborhoods," said one of the residents who was enthusiastic about helping to improve 'his own neighborhood.' "Fortunately, recently-proposed pedestrian bridges over the expressways are soon to be in place," he added. 


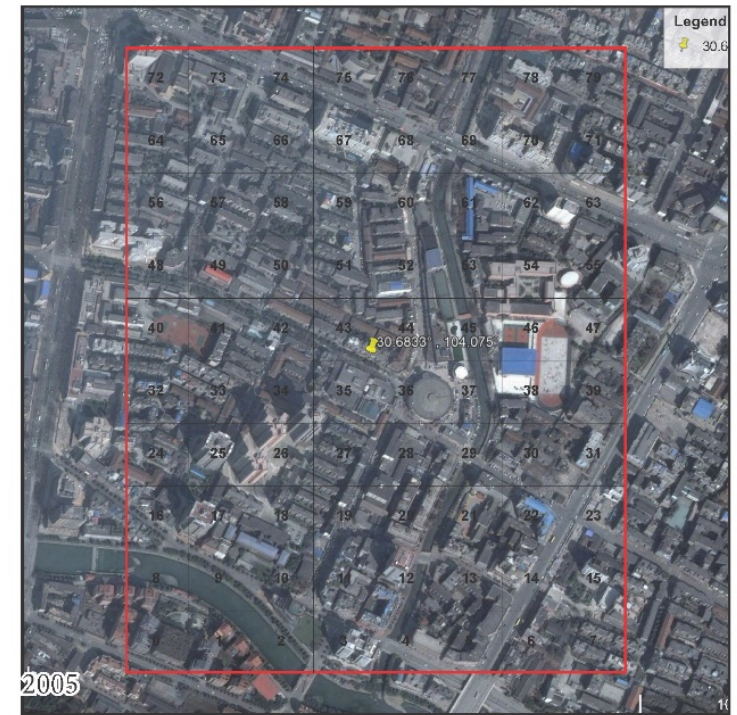

Satellite image, 2005

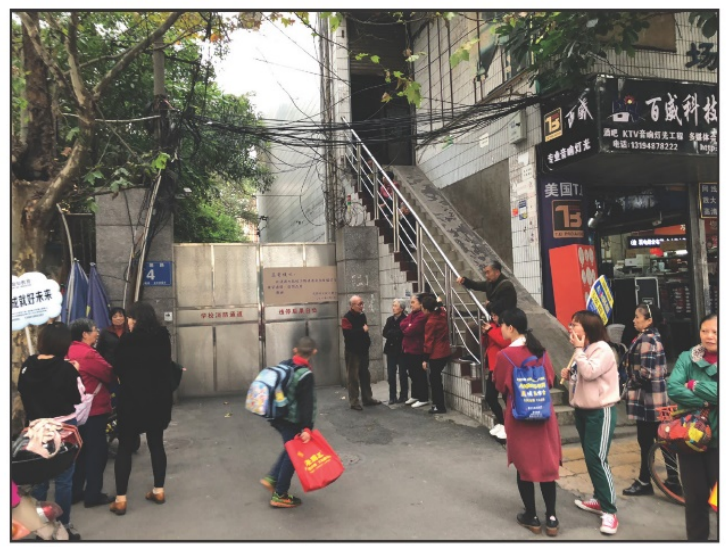

Public space

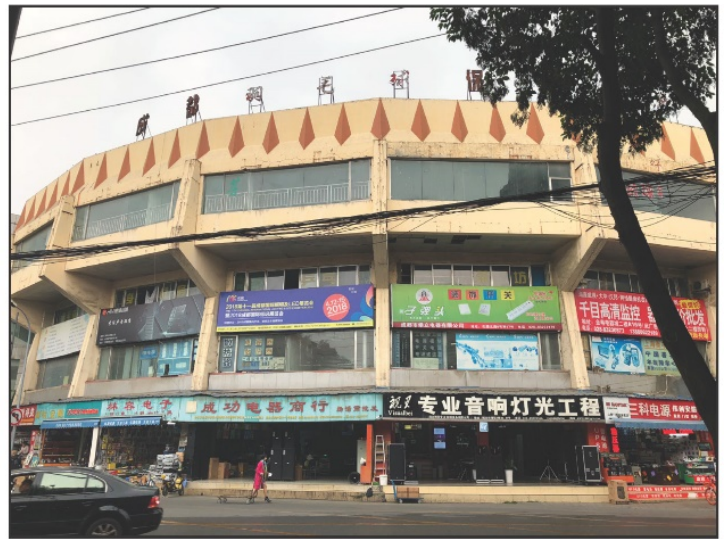

Food market and shopping

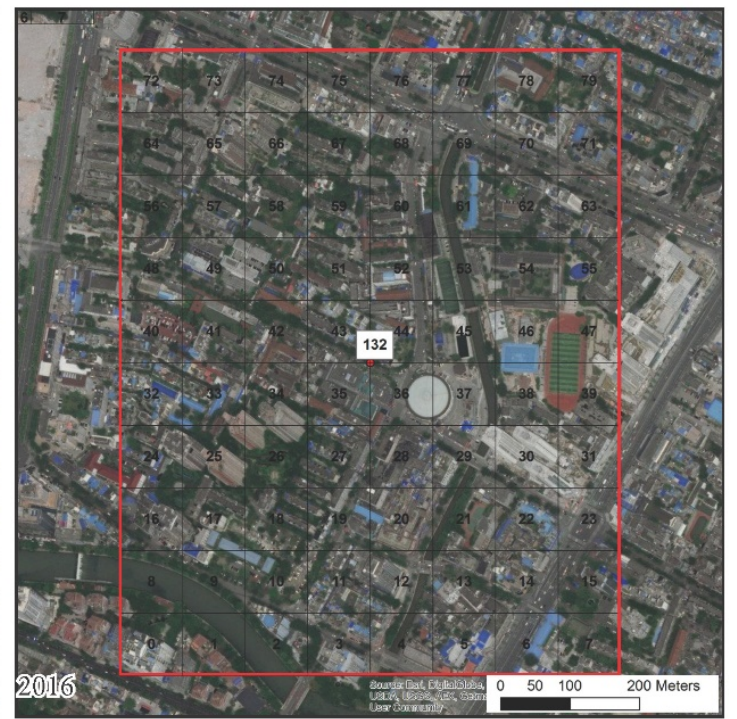

Satellite image, 2005

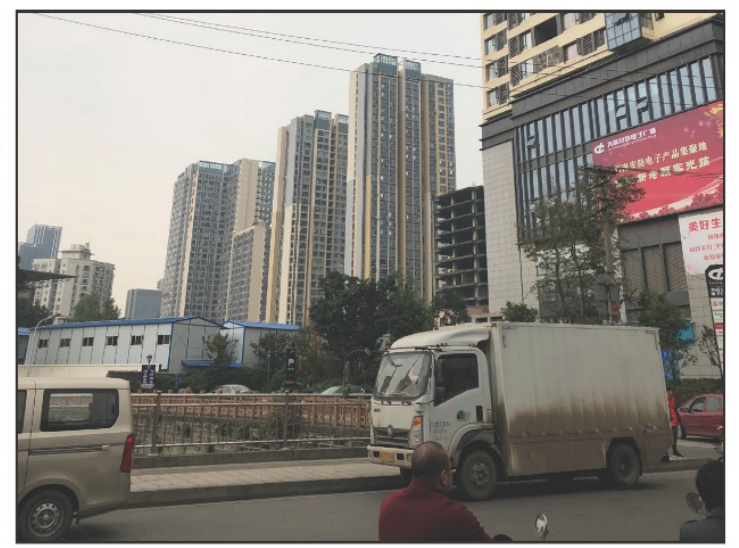

Street network for pedestrians and cyclists

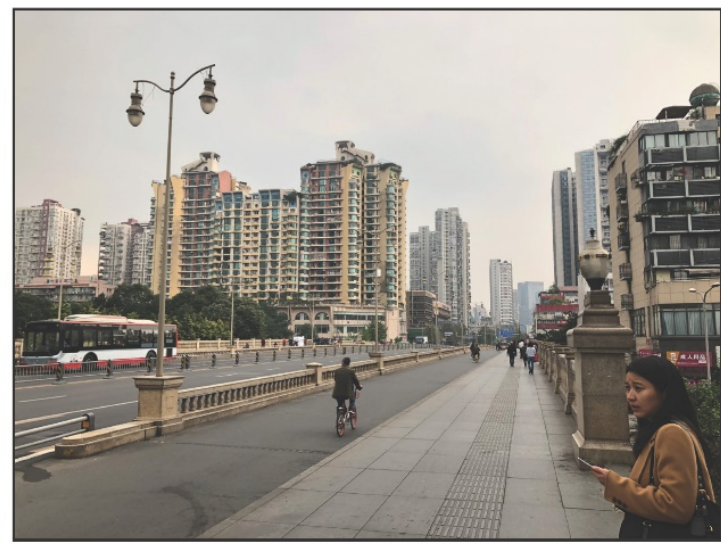

Connectivity to outside of the neighborhood

Figure 2. Mixed-use neighborhood.

Sources for Figures 1 to 4: The top row images were extracted from Baidu Map; the middle and lower pictures were taken during a field trip in 2017. 


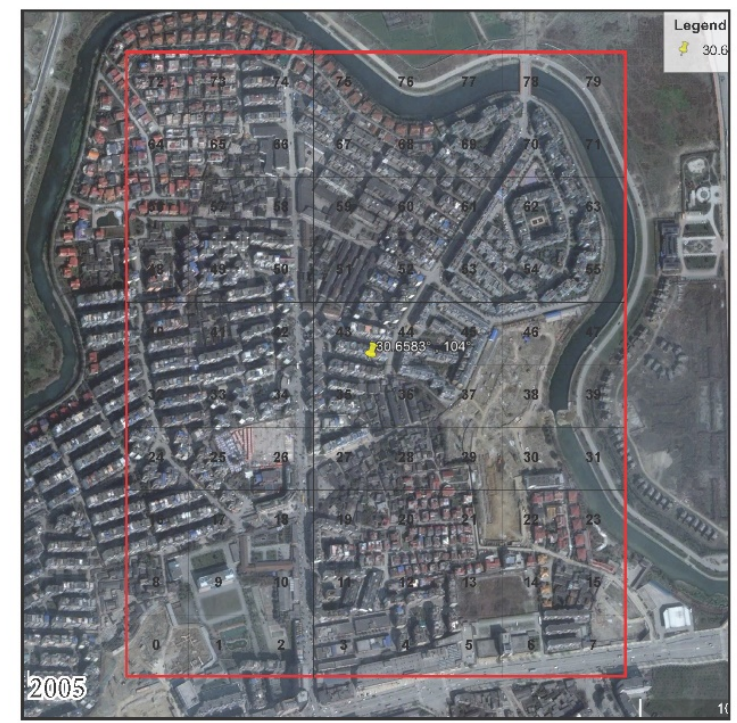

Satellite image, 2005
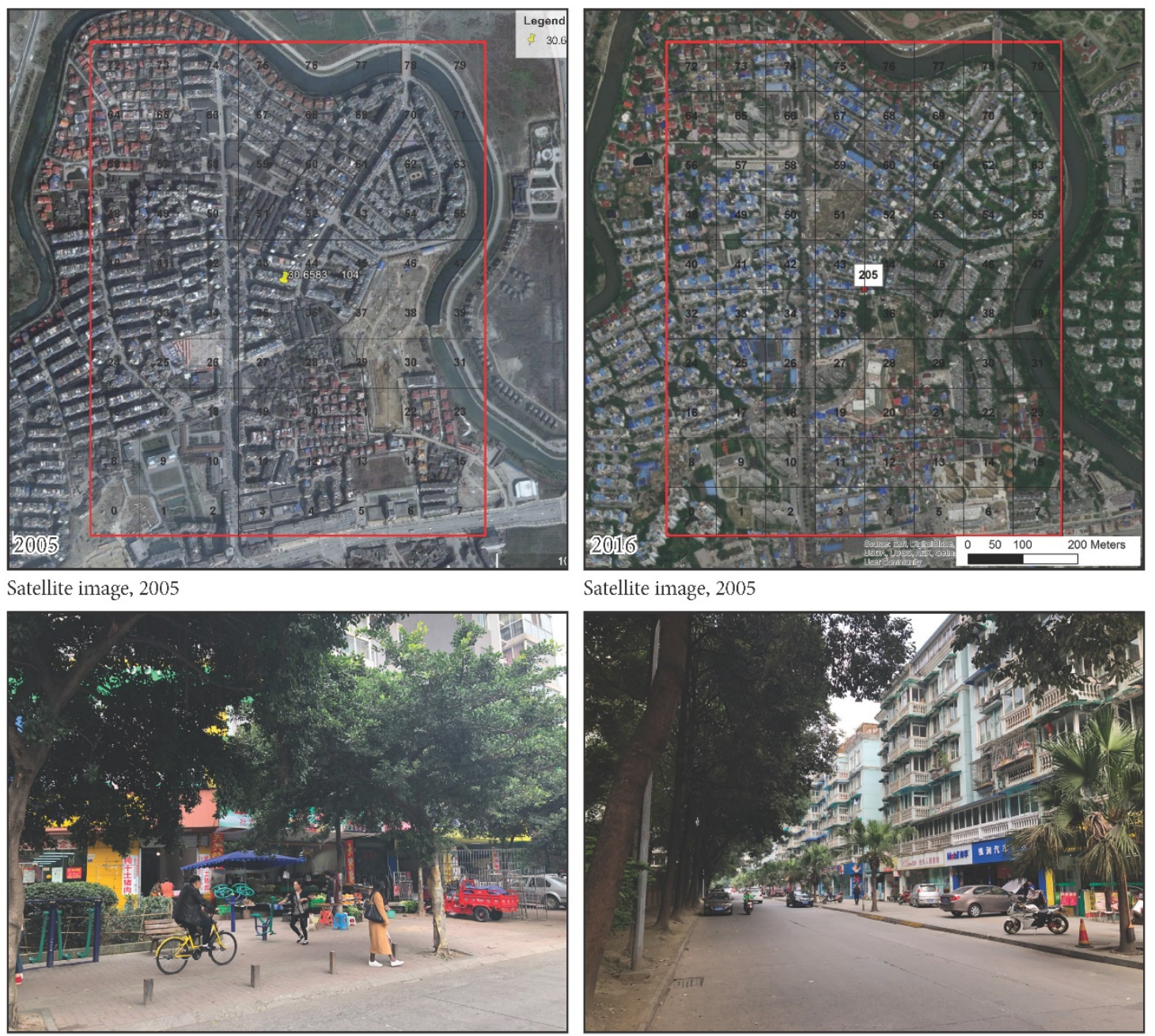

Satellite image, 2005

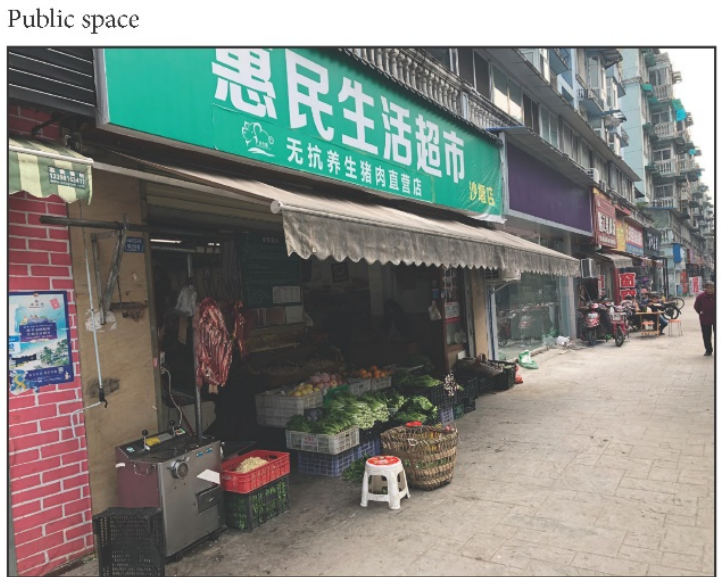

Food market and shopping

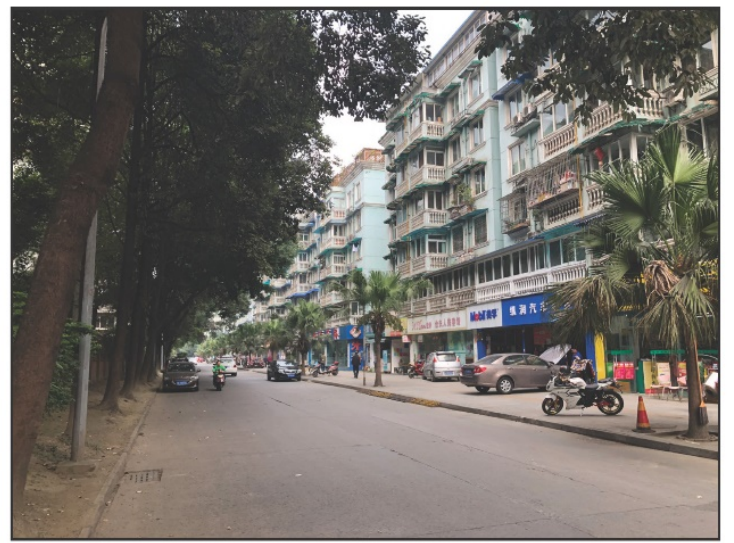

Street network for pedestrians and cyclists

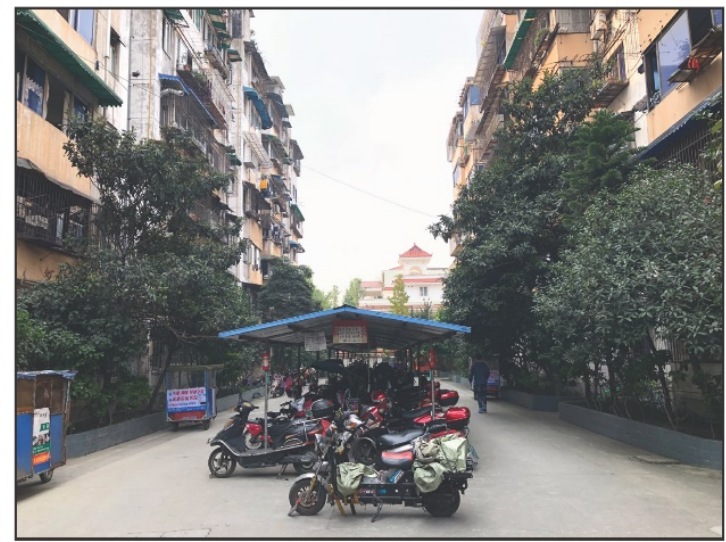

Connectivity to outside of the neighborhood

Figure 3. Slab block apartment. 

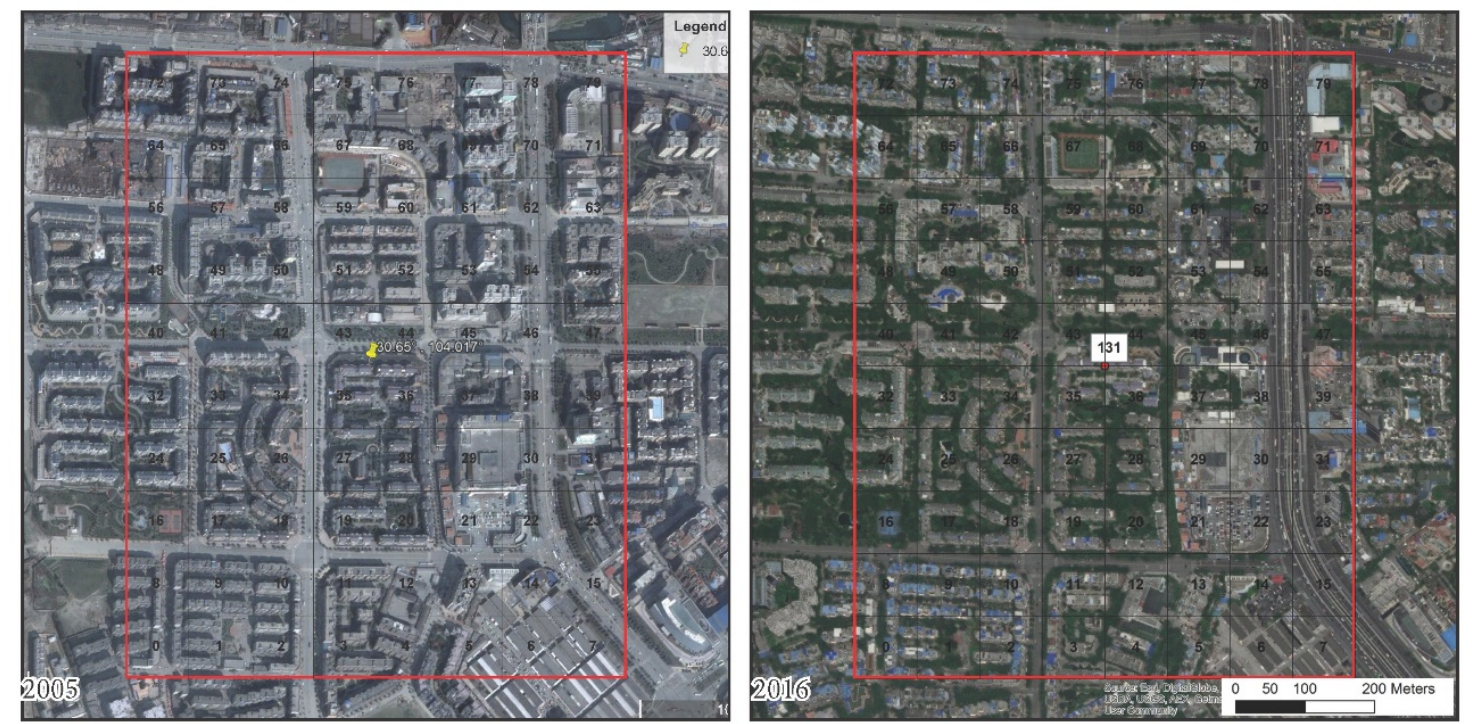

Satellite image, 2005

Satellite image, 2005
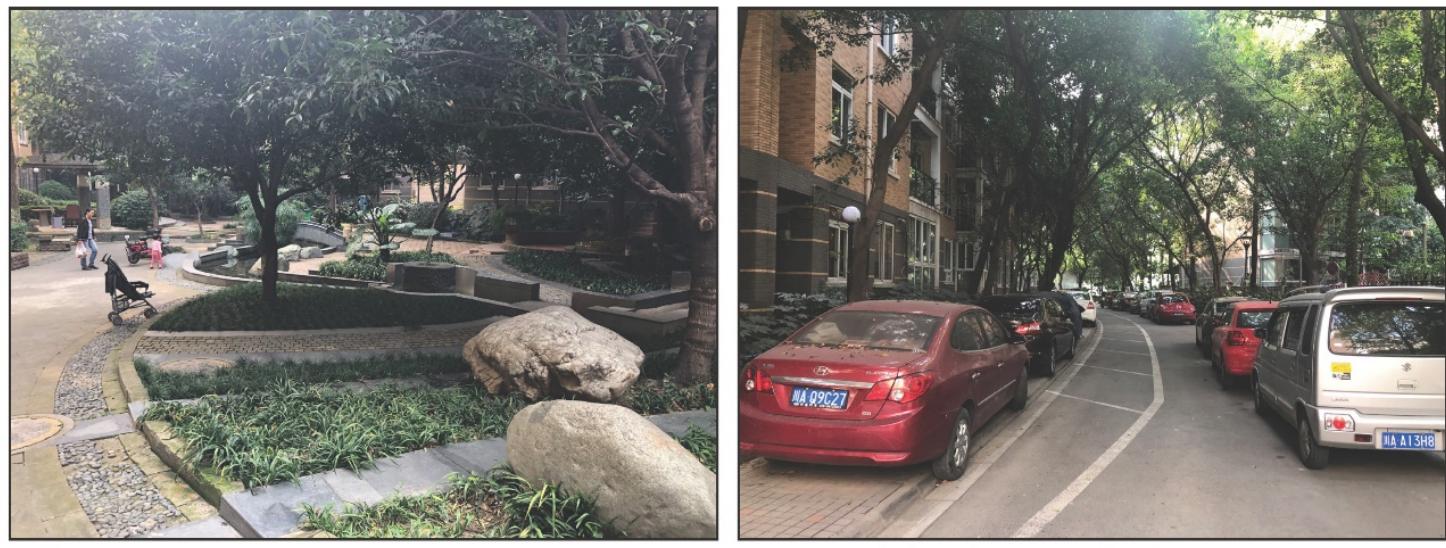

Public space

Street network for pedestrians and cyclists

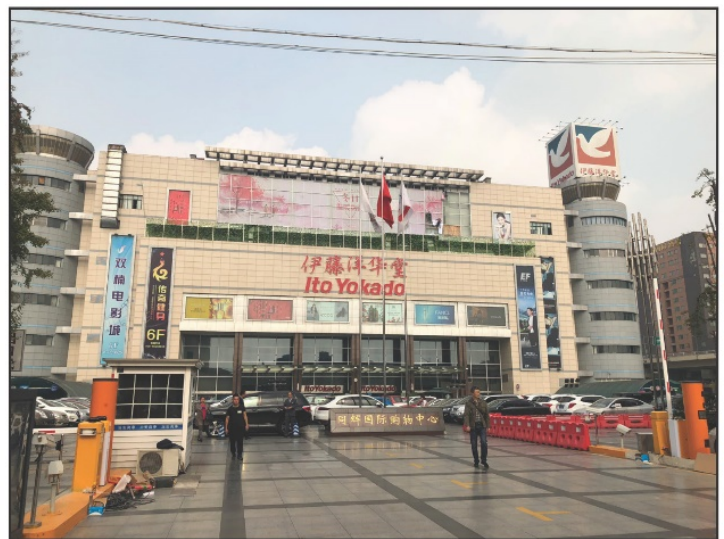

Food market and shopping

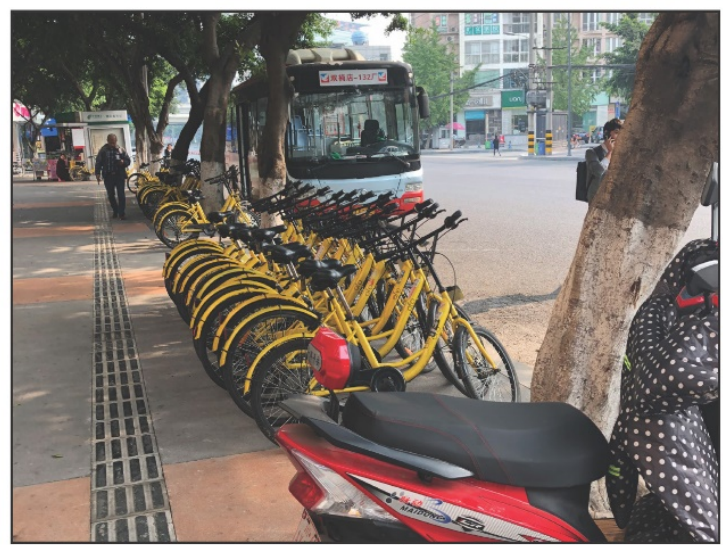

Connectivity to outside of the neighborhood

Figure 4. Gated community. 


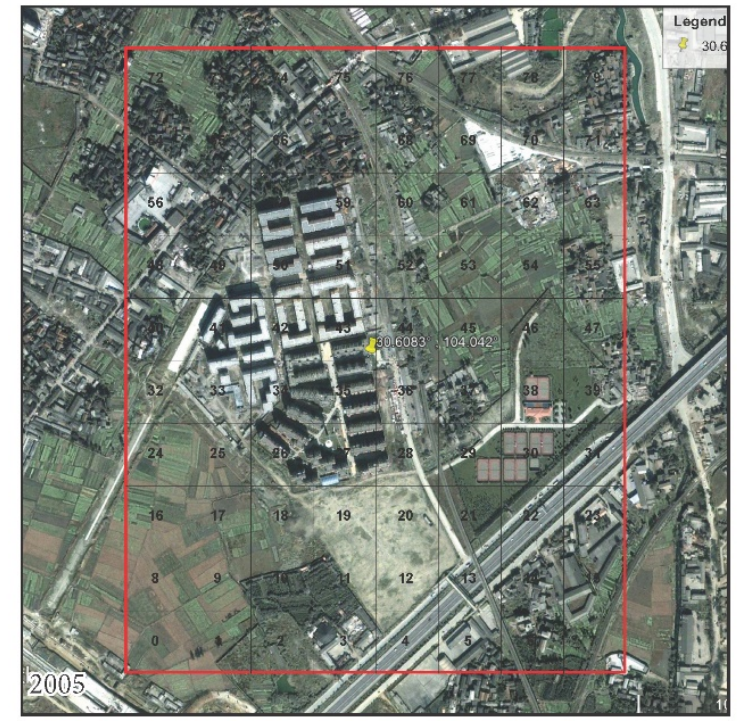

Satellite image, 2005

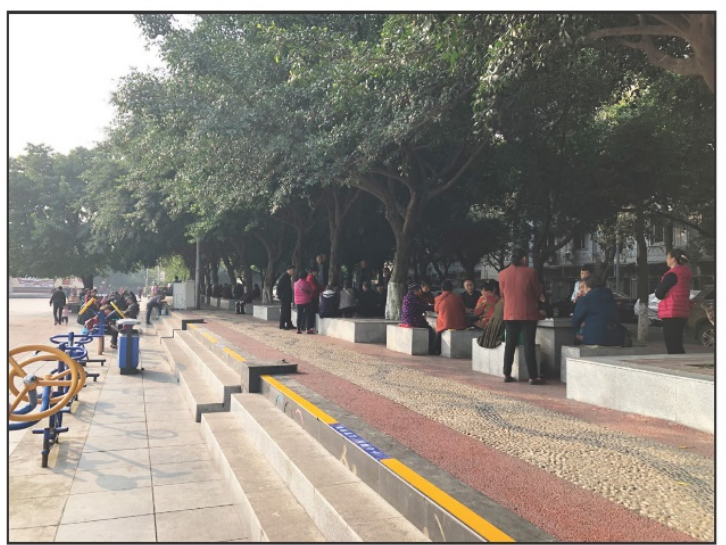

Public space

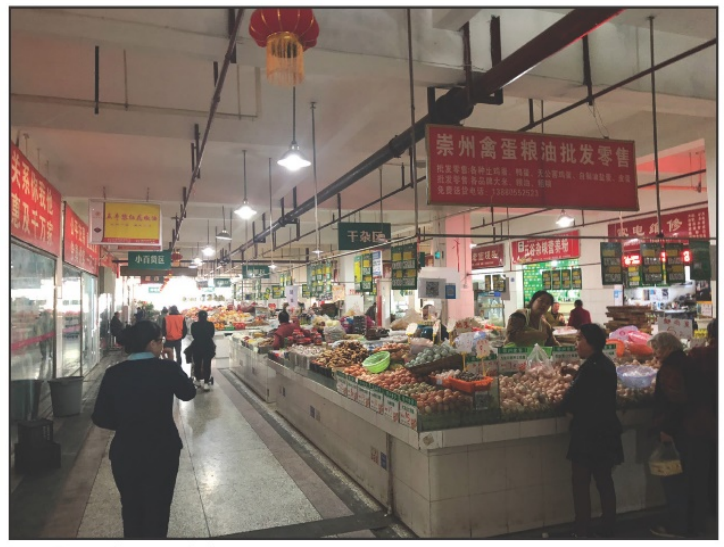

Food market and shopping

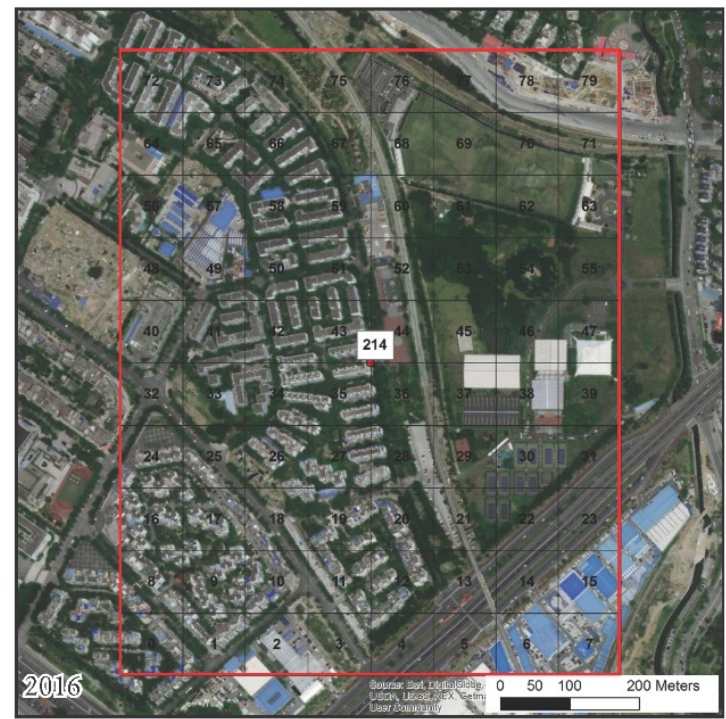

Satellite image, 2005

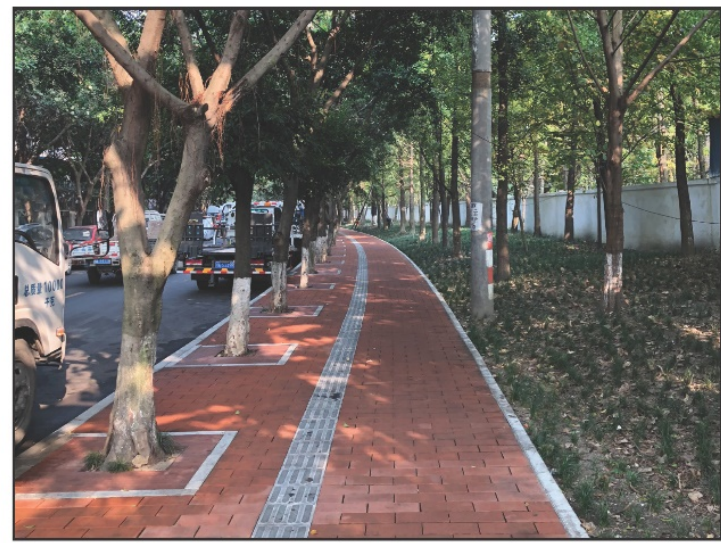

Street network for pedestrians and cyclists

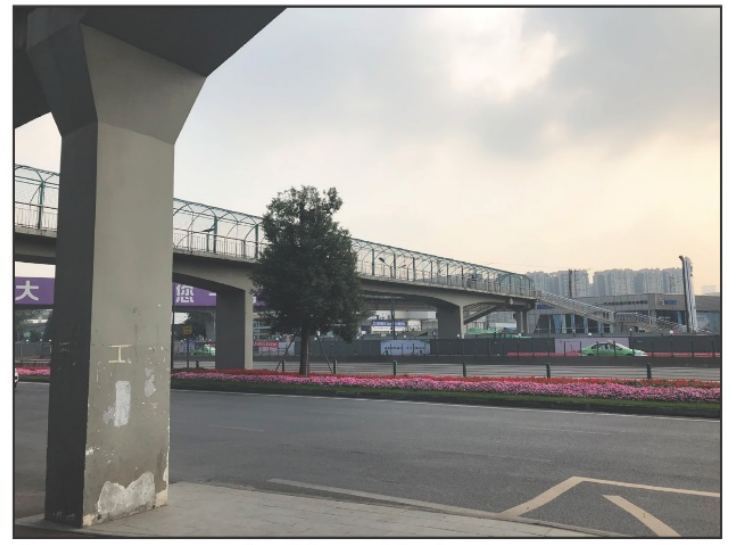

Connectivity to outside of the neighborhood

Figure 5. Resettlement housing. 


\section{Discussion}

To promote active transport in Chengdu, each neighborhood should be addressed with tailormade urban planning strategies, design solutions, and policy interventions. For the mixed-use neighborhood in Renmin Beilu, smaller open spaces for social activities within the neighborhoods should be provided. It seems straightforward that there should be more space outside schools for adults to pick up and drop off schoolchildren, without blocking pedestrian circulation. In addition, consolidation of the retail stores would enhance accessibility to housing estates within the neighborhood.

In the slab block neighborhood in Sunjia Wan, urban regeneration has resulted in gentrification and a few high-density luxury residential projects. The added density and ongoing construction has resulted in more traffic, jeopardizing the safety of pedestrians and cyclists. The already dilapidated street network has received no attention or financial support. There is an urgent need to update infrastructure, provide neighborhood public space, grant public access to privately operated riverbank space, and encourage retail or commercial stores to move in. More importantly, large scale development projects that would exacerbate traffic congestion and bring more cars to the neighborhood should be reconsidered. In this neighborhood, as well as in many other work-unit type of neighborhoods in Chengdu, strategies should be formulated not only for low-income urban residents and floating population, but also for organizations that are designated for disadvantaged groups and socially vulnerable groups, such as social service centers for disabled, to be located in the heart of the neighborhood.

Opening up the gated community should not be as simple as taking away the iron doors; it should create within the residents' a sense of community which has been long absent. It is not clear that this would encourage more active travel by locals as well as by travelers passing through from outside of the community unless it is accompanied by policies that favor active transport. The following points should be prioritized to make gated communities more walkable: (1) provide more parking space; (2) diversify land use function; and (3) reconfigure the spatial layout of the neighborhood.

In the resettlement housing neighborhood, it needs to be acknowledged that low-income households have a low car ownership. Social economic conditions constrain the residents from finding employment in their own community because of a lack of social networks. Low accessibility to the city center and low connectivity to the other parts of the city are the main 
reasons preventing residents from participating in activities outside of the neighborhood. The solution may be to bring employment opportunities closer to the community through transit oriented development though this may result in gentrification pushing out such residents as seen in Sunjia Wan.

\section{Conclusions}

As predicted by studies from ten years ago (Pan et al., 2009), coastal cities in China are becoming more car dependent. This study confirms that Chengdu, an inland city in China, follows the claims of previous studies on coastal cities (Zhao and Chai, 2013; Shen et al., 2015) that residents in work-unit neighborhoods are more likely to take active transport than other types of neighborhoods for work trips. In addition, this study finds that residents in gated community are less likely to choose active transport for work trips, which also confirms the claims of previous studies. For non-work trips, however, contrary to previous studies on coastal cities (Pan et al., 2009; Zhao and Chai, 2013), the results of this study suggest that work unit neighborhoods in Chengdu do not promote active transport. Moreover, residents in resettlement neighborhoods choose the least active mode of travel, again this is in contradiction to some previous studies on coastal cities in China. We found that neighborhood type in Chengdu does affect travel behavior such as choice of active transport but in a different way from studies of coastal cities in China.

In future studies of active transport, we should give emphasis to the differences between coastal and inland cities in China. Coastal cities started their economic reforms earlier than most of the inland cities. The priority at the time was on the efficacy of urban growth while promoting active transport was not emphasized. Today, inland cities are catching up with coastal cities on car ownership, rapid population growth (for example, through intra-provincial migration), and land expansion (urban sprawl). At this critical moment, we need to think about what lessons can inland cities learn from coastal cities and also the new challenges inland cities are facing to promote active transport. For example, the transformations of work-unit neighborhood in inland cities, different from many coastal cities, are happening simultaneously with the emergent of resettlement housing issues.

There are limitations to this study. We chose only four neighborhoods for onsite interviews and we do not have information on their spatial transformation over time. We plan to conduct 
more onsite interviews for all 40 neighborhoods, after which we can better understand the choice of active transport in each neighborhood type. In future studies we will also consider how shorter and longer trips can be affected differently in work-unit neighborhoods, as they are transforming rapidly (in terms of density, diversity, and accessibility measures) in inland Chinese cities like Chengdu. In addition, the categorization of neighborhood could also change the results. For example, some resettlement housing can also be gated communities of high living standard. A sensitivity analysis will be conducted for future studies. Moreover, to explore walking and cycling separately could provide more specific recommendations for transport planning.

The findings of this study suggest different strategies for promoting active transport: (1) the traditional mixed-use neighborhoods are in need of intensified urban retrofitting projects to reclaim public open space; (2) the slab block work-unit neighborhoods can benefit from comprehensive plans rather than a patch-up of individual pieces; (3) while opening up gated communities can help improve neighborhood porosity and promote active transport, the most pressing issue is perhaps their obsolete spatial dimensions and functions; and (4) resettlement housing should be integrated into the city.

\section{References}

1. Alonso, W., 1964. Location and land use. Cambridge, MA: Harvard University Press.

2. Ben-Akiva, M., Lerman, S.R., 1985. Discrete Choice Analysis. Cambridge, MA: MIT Press.

3. Bhat, C.R., Sen, S., Eluru, N., 2009. The impact of demographics, built environment attributes, vehicle characteristics, and gasoline prices on household vehicle holdings and use. Transportation Research Part B: Methodological 43(1), 1-18.

4. Bray, D., 2005. Social Space and Governance in Urban China: The Danwei System from Origins to Reform. Stanford: Stanford University Press.

5. Cao, X, 2010. Exploring causal effects of neighborhood type on walking behavior using stratification on the propensity score. Environment and Planning A: Economy and Space 42(2), 487-504.

6. Cao, X. (Jason), Mokhtarian, P.L., Handy, S.L., 2009. The relationship between the built environment and nonwork travel: A case study of Northern California. Transportation Research Part A: Policy and Practice 43(5), 548-559.

7. Cao, X., 2015. Examining the impacts of neighborhood design and residential self-selection on active travel: a methodological assessment. Urban Geography 36(2), 236-255.

8. Cervero, R., 2007. Transit-oriented development's ridership bonus: A product of selfselection and public policies. Environment and Planning A: Economy and Space 39(9), 2068-2085. 
9. Cervero, R., 2013. Linking urban transport and land use in developing countries. Journal of Transport and Land Use 6, 7-24.

10. Chengdu Statistics Bureau, 2017. Chengdu Statistics Yearbook 2016. Chengdu: Chengdu Statistics Press.

11. Day, K., 2003. New Urbanism and the challenges of designing for diversity. Journal of Planning Education and Research, 23(1), 83-95.

12. Ewing, R., Cervero, R., 2010. Travel and the built environment: a meta-analysis. Journal of American Planning Association, 76(3), 265-294.

13. Feng, J., Dijst, M., Wissink, B., Prillwitz, J., 2014. Understanding mode choice in the Chinese context: The case of Nanjing metropolitan area. Tijdschrift Voor Economische En Sociale Geografie 105(3), 315-330.

14. Feng, J., Dijst, M., Wissink, B., Prillwitz, J., 2017. Changing travel behaviour in urban China: Evidence from Nanjing 2008-2011. Transport Policy 53, 1-10.

15. Forsyth, A., Crewe, K., 2009. A Typology of Comprehensive Designed Communities Since the Second World War. Landscape Journal 28(1), 56-78.

16. Forsyth, A., Krizek, K.J., 2010. Promoting walking and bicycling: Assessing the evidence to assist planners. Built Environment 36(4), 429-446.

17. Gao, M., Ahern, J., Koshland, C.P., 2016. Perceived built environment and health-related quality of life in four types of neighborhoods in Xi'an, China. Health and Place 39, 110-115.

18. Giuliano, G., Narayan, D., 2003. Another look at travel patterns and urban form: the US and Great Britain, Urban Studies 40(11), 2295-2312.

19. Guan, C., Srinivasan, S., Nielsen, C., 2019. Does neighborhood form influence low-carbon transportation in China? Transportation and Research Part D: Transport and Environment 67, 406-420.

20. Handy, S.L., Clifton, K.J., 2001. Local shopping as a strategy for reducing automobile travel. Transportation 28(4), 317-346.

21. Hu, L., Sun, T., Wang, L., 2018. Evolving urban spatial structure and commuting patterns: A case study of Beijing, China. Transportation and Research Part D: Transport and Environment 59, 11-22.

22. Huang, Y., 2003. Renters' housing behaviour in transitional urban China. Housing Studies $18(1), 103-125$.

23. Huang, Y., 2004. The road to homeownership: a longitudinal analysis of tenure transition in urban China (1949-93). International Journal of Urban and Regional Research 28(4), 774795.

24. Kan, H. Y., Forsyth, A., Rowe, P., 2017. Redesigning China's superblock neighbourhoods: policies, opportunities and challenges. Journal of Urban Design 22(6), 757-777.

25. Kwan, M.P., 1998. Space-time and integral measures of individual accessibility: A comparative analysis using a point-based framework. Geographical Analysis, 30(3), 191-216. 
26. Lin L., 2018. Leisure-time physical activity, objective urban neighborhood built environment, and overweight and obesity of Chinese school-age children. Journal of Transport \& Health. In press.

27. Lu, D., 2006. Traveling urban form: the neighborhood unit in china. Planning Perspectives, 21(4), 369-392.

28. Miller, E., 2018. Accessibility: measurement and application in transportation planning. Transport Reviews 38(5), 551-555.

29. National Resources Defense Council, 2017. The China Urban Walkability Report. https://www.nrdc.org/china

30. Pan, H., Shen, Q., Zhang, M., 2009. Influence of urban form on travel behaviour in four neighborhoods of Shanghai. Urban Studies 46(2), 275-294.

31. Qin, B., 2015. City profile: Chengdu. Cities 43, 18-27.

32. Perry, C.A., 1929. The neighborhood unit: A scheme of arrangement for the family-life community. In Regional study of New York and its environs, VIII, neighborhood and community planning, Monograph 1, 22-140.

33. Rodríguez, D.A., Khattak, A.J., Evenson, K.R., 2006. Can new urbanism encourage physical activity? Comparing a new urbanist neighborhood with conventional suburbs. Journal of the American Planning Association 72(1), 43-54.

34. Rowe, P., Forsyth, A., Kan, H., 2016. China's Urban communities: Concepts, contexts, and well-being. Basel: Birkhauser.

35. Schwanen, T., Mokhtarian, P.L., 2005. What affects commute mode choice: Neighborhood physical structure or preferences toward neighborhoods? Journal of Transport Geography 13, 83-99.

36. Shen, Q., 2000. Spatial and social dimensions of commuting. Journal of the American Planning Association 66(1), 68-82.

37. Shen, Y., Chai, Y., Kwan, M., 2015. Space-time fixity and flexibility of daily activities and the built environment: A case study of different types of communities in Beijing suburbs. Journal of Transport Geography 47, 90-99.

38. State Council, 1998. A notification from the State Council on further deepening the reform of urban housing system and accelerating housing construction. State Council Documentation, No. 23. (in Chinese).

39. State Council, 2016. Some guidelines to further reinforce the management of urban planning and construction. Xinhua News Agency.

40. Wang D., Chai, Y., Li, F., 2011. Built environment diversities and activity-travel behavior variations in Beijing, China. Journal of Transport Geography 19(6), 1173-1186.

41. Wang, D., Zhou, M., 2017. The built environment and travel behavior in urban China: A literature review. Transportation Research Part D: Transport and Environment 52, 574-585.

42. Yang, J., 2005. The Spatial and Temporal Dynamics of Commuting: Examining the Impacts of Urban Growth Patterns, 1980-2000. Department of Urban Studies and Planning, PhD 
Thesis, 1980-2000.

43. Yuan, T., 2010. The history of streets in Chengdu. Chengdu: Sichuan Publisher Group (in Chinese).

44. Zhao, Y., Chai, Y., 2013. Residents' activity-travel behavior variation by communities in Beijing, China. Chinese Geographical Science 23(4), 492-505.

Appendix 1. Sample questions of the 2016 survey - vehicle ownership.

A10 Do you take public transit buses on a regular basis?

A11 Do you have an IC card?

A13 Do you have a driver's license?

A14 Aside from yourself, how many people in your household have a driver's license?

A16B1 a1 Number of privately owned bicycle (pedal)(b)

A16A1C1 Approx purchase cost of bicycle (pedal) one $(\mathrm{C} 1)$

A16A1C2 Approx purchase cost of bicycle (pedal) two(C2)

A16A1C3 Approx purchase cost of bicycle (pedal) three(C3)

A16D1 a1Number of bicycle (pedal)provided by employer (d)

A16B2 a2Number of privately owned bicycle (electric / motorized)(b)

A16A2C1 Approx purchase cost of bicycle (electric / motorized) one $(\mathrm{C} 1)$

A16A2C2 Approx purchase cost of bicycle (electric / motorized) two $(\mathrm{C} 2)$

A16A2C3 Approx purchase cost of bicycle (electric / motorized) three(C3)

A16D2 a2Number of bicycle (electric / motorized)provided by employer (d)

A16B3 a3Number of privately owned tricycle(b)

A16A3C1 Approx purchase cost of tricycle one $(\mathrm{C} 1)$

A16A3C2 Approx purchase cost of tricycle two(C2)

A16A3C3 Approx purchase cost of tricycle three(C3)

A16D3 a3Number of tricycle provided by employer (d)

A16B4 a4Number of privately owned motorcycle(b)

A16A4C1 Approx purchase cost of motorcycle(one)(C1)

A16A4C2 Approx purchase cost of motorcycle(two)(C2)

A16A4C3 Approx purchase cost of motorcycle(three)(C3)

A16D4 a4Number of motorcycle provided by employer (d)

A16B5 a5Number of privately owned passenger car(b)

A16A5C1 Approx purchase cost of passenger car(one $)(\mathrm{C} 1)$

A16A5C2 Approx purchase cost of passenger car(two)(C2)

A16A5C3 Approx purchase cost of passenger car(three)(C3)

A16D5 a5Number of passenger car provided by employer (d)

A16B6 a6Number of privately owned bus or other more than six passengers car(b)

A16A6C1 Approx purchase cost of bus or other more than six passengers car(one $)(\mathrm{C} 1)$

A16A6C2 Approx purchase cost of bus or other more than six passengers car(two $)(\mathrm{C} 2)$

A16A6C3 Approx purchase cost of bus or other more than six passengers car(three)(C3)

A16D6 a6Number of bus or other more than six passengers car provided by employer (d) 
A16B7 a7Number of privately owned truck, van, or other 4-wheel freight- carrying vehicle(b)

A16A7C1 Approx purchase cost of truck, van, or other 4-wheel freight- carrying vehicle(one)(C1)

A16A7C2 Approx purchase cost of truck, van, or other 4-wheel freight- carrying vehicle(two)(C2)

A16A7C3 Approx purchase cost of truck, van, or other 4-wheel freight- carrying vehicle(three)(C3)28

A16D7 a7Number of truck, van, or other 4-wheel freight- carrying vehicle total number of privately car (d)

A16B77 a77Number of privately owned other car (incl

A16A77C1 Approx purchase cost of other car(one)(C1)

A16A77C2 Approx purchase cost of other car(two)(C2)

A16A77C3 Approx purchase cost of other car(three)(C3)

A16D77 a77Number of other car provided by employer (d)

A16D90A a90 Total number of privately cars

A16D90A1 a90 Total number of cars total number of privately car

A17 You plan to buy a car or other type of motor vehicle within a year?

A18S1 The reasons that you want to own a car?(Time saving)

A18S2 The reasons that you want to own a car?(Safety)

A18S3 The reasons that you want to own a car?(Comfort)

A18S4 The reasons that you want to own a car?(Social status)

A18S5 The reasons that you want to own a car?(Business)

A18S6 The reasons that you want to own a car?(Public transit is not good)

A18S7 The reasons that you want to own a car?(Convenience)

A18S77 The reasons that you want to own a car?(Other)

A18S77K The reasons that you want to own a car? Other (specify) 